\title{
Music as performance - gestures, sound and energy
}

\section{A discussion of the pluralism of research methods in performance studies}

\author{
Tanja Orning* \\ Norwegian Academy of Music
}

\begin{abstract}
The aesthetic project in a number of contemporary works composed after World War II has led to major changes and challenges within key areas such as notation, idiomaticism, interpretation, the performer's role and the work concept. This new musical aesthetic, employing performative energy, instrumental practice and gestures as compositional material requires an analytical approach that corresponds to the nature and demands of the music in performance. A fundamental question is how to understand music, not as a work written in a score but as a living object, as performance, sound, action and embodiment. To research this within music brings about new methodological challenges. In this article, the author discusses possible methods in approaching and investigating performance practice in music, specifically in contemporary cello music, guided by the research question: How can I relate and network the pluralism of methods in music research involving artistic practice?
\end{abstract}

Keywords: Artistic research; performance studies; performance practice; methodology; contemporary cello

\section{Sammendrag}

Det estetiske prosjektet i en rekke samtidsverk komponert etter krigen har ført til store endringer og utfordringer innenfor nøkkelområder som notasjon, idiomatikk, tolkning, utøverens rolle og verkbegrepet. Denne nye musikalske estetikken som utnytter utøverens energi, instrumentalpraksis og gester som komposisjonsmateriale, krever en analytisk tilnærming som korresponderer med musikkens egenskaper og kravene fremføring av musikken stiller. Et grunnleggende spørsmål er hvordan vi forstår musikken, ikke som et verk nedskrevet i et partitur, men som et levende objekt, som fremføring, lyd, klang, handling og kroppsliggiøring. Å undersøke dette i musikk, fører til nye metodologiske utfordringer. I denne artikkelen diskuterer forfatteren mulige metoder for å nærme seg og undersøke fremføringspraksis i musikk, spesielt i samtidsmusikk for cello, ledet av forskningsspørsmålet: Hvordan kan jeg forholde meg til og nettverke metodepluralismen i musikkforskning som involverer kunstnerisk praksis?

${ }^{\star}$ Correspondence to:Tanja Orning, Norwegian Academy of Music, Slemdalsveien 11, 0369 OSLO. Email: tanja.orning@nmh.no 
Nøkkelord: Kunstnerisk forskning; performancestudier; performative praksiser; metodologi; samtidsmusikk for cello

Received: May, 2017; Accepted: October, 2017; Published: December, 2017

In this article, I draw on two case studies from my PhD work (Orning, 2014) where I use my own experiences as a cellist in the investigation of works by Morton Feldman and Helmut Lachenmann. In this, I alternate between the road "from practice to theory" and "from theory to practice". My practice trajectory, a result of my background, education and experience, is embedded in a wider narrative framed by a larger field of musicology. This field of tension produces different kinds of knowledge and knowing: an epistemic complexity (de Assis, 2015), which requires a pluralism of research methods. In this article, I look at the relational interplay between several agents including performance, performer, instrument, work, composer, performance space and audience. I draw on methodological and theoretical concepts of relevance such as performance studies, artistic research, action research, Donald Schön's concept of reflection-in-action, theories of tacit knowledge and literary theory.

After the presentation of the case studies, I extend the perspective from this specific study to explore a wider framework of artistic research, and discuss the discoveries made in the case study.

\section{The performative turn}

Historically, musical performance has not been subjected to much research. However, recent decades have seen a reflexive turn in musicology, where performers in various genres have started to study their own practices through reflecting upon and documenting their own artistic processes. This has coincided with the performative turn in the arts, a paradigm shift that took place in the humanities in the 1990s. The performative turn acknowledged the social construction of reality through the suggestion that all human practices are performed. ${ }^{1}$ In musicology, the performative turn (Cook, 2015, p.13) seriously challenged the image of the musical score as a carrier and transmitter of objective knowledge. ${ }^{2}$ It led to a replacement of essentialist conceptions by a more dynamic understanding of the musical work, which is no longer viewed as a finished work but as an aesthetic event perpetually changing through each performance. The historical distinction between knowing and doing and texts

${ }^{1}$ See Gender trouble: Feminism and the subversion of identity, Judith Butler (2006), and The Practice Turn in Contemporary Theory, eds Karin Knorr Cetina, Theodore R. Schatzki, Eike von Savigny (2001).

${ }^{2}$ The performative turn in musicology has been theorized by a number of musicologists and philosophers, including Richard Taruskin (1995), Lydia Goehr (1992, 1998) and Nicholas Cook (1999, 2003, 2013, 2015). 
and acts in musicology, has produced analysis predominantly based on theory and text. But the investigation of music as action and performance requires a different set of perspectives and tools than a straightforward textual analysis. As the performance itself becomes the object of study, scholars negotiate concepts like embodiment, action, behaviour, agency and perhaps the most illustrating word: liveness.

In the wake of the performative turn, artistic research, performance studies and practice-based research have made their way into academia, establishing $\mathrm{PhD}$ and post-doctoral programmes. My PhD project, "The Polyphonic Performer" (Orning, 2014) was carried out within the doctoral programme at The Norwegian Academy of Music in the research programme for "performance practice." Projects within this programme use musical performance as significant material in their research, either through the performing researcher, or in investigating performance-related topics or perspectives.

\section{Artistic research and methods}

Artistic research is an umbrella term, embracing a multitude of approaches and methodologies in research involving artistic practice. Rather than making a distinction between artistic and academic research, Henk Borgdorff, philosopher, music theorist and a central figure in the field of artistic research, advocates methodological pluralism, saying that multiple methodological approaches from other disciplines may play a complimentary part in artistic research (Borgdorff, 2010, p. 46). Performer and researcher Mine Doğantan-Dack refers to artistic research as:

[...] research activities that are methodologically integrated with an artistic creation and cannot be pursued without art-making. In this sense, the domain of artistic research does not necessarily overlap with that of 'practice-based' research where the practice involved does not always result in an art-product (Doğantan-Dack, 2012, p. 36).

Practice-based or practice-led research (Haseman, 2006; Nelson, 2013) is undertaken by practitioners in various disciplines, and its primary aim is to develop new understandings about practice from within practice.

Borgdorff discusses three perspectives on the status of art practice within artistic research, distinguishing between research on the arts, for the arts, and in the arts:

The interpretative perspective ("research on the arts") is common to the research traditions of the humanities and social sciences, which observe a certain theoretical distance when they make art practice their object of study [...] The instrumental perspective ("research for the arts") is characteristic of the more applied, often technical research done in the service of art practice [...] In this case, art practice is not the object of study, but its objective [...] We can justifiably speak of artistic research ("research in the arts") when that artistic practice is not only the result of the research, but also its methodological vehicle, when the research unfolds in and through the acts of creating and performing (Borgdorff, 2010, p. 46). 


\section{T. Orning}

In my research on performance practice, I am dependent on artistic practice as a vehicle, tool or method. From this perspective, my study can clearly be positioned within artistic research. My object of study is performance practice within contemporary music, which I examine in and through performance. But I also take one step back and look on performance practice in a contextual and historical perspective. My research is also for practice, as an underlying drive of my practitioner research is a curiosity to explore phenomena in order to develop, change and improve practice, both in technical and aesthetical areas.

\section{Search and research}

Questioning what is research in the arts? Raes distinguishes between search and research:

[...] it is also necessary for the object of research to be problematic and for the problem to have a demonstrable significance. The latter must certainly supersede the significance it has for the individual researcher. A painter wrestling with perspective, a composer tying himself in knots over problems of orchestration, a performer struggling with a highly complex score [. . . these people are searching, but not researching. That is, and remains, a fundamental distinction. Creating art, practising it, with whatever degree of excellence, cannot simply be conflated with research in art. Art and research are not the same thing, although they may occur together (Raes, 2014, p. 56).

For artistic practice to be understood as research, it needs questions and problem areas: there must be something at stake, important issues that needs to be investigated.

When research originates in practice, it is a "bottom up" perspective, an inside-out approach of investigating a problem area through practice, aiming at gaining from the relationship between studying and doing performance. A danger of the insider position of the artist is however, that "the distinction between subject and object becomes so blurred at that point that the research result can be considered purely egotistical" (Raes, 2014, p. 55-56). In artistic research, the subjective experiences from inside the practice needs to be problematized, discussed, questioned, taken apart and reassembled in different configurations. For the implicit knowledge, the embodied knowledge, the artistic knowledge to be called research, it has to be sharpened and honed with something from outside the practice. How we do this and what we choose to be our tools, our metaphorical whetstone and optics, our doing and thinking tools and objects, can be called a method (from Greek meta, after, and hodos, way), the ways we choose to follow. Methods are something that help us investigate phenomena, which may be theoretical lenses or concrete procedures. Methods open the world to different perspectives, questioning and conversing with materials and texts. In research on musical practice, there are no ready-made methods. It is a young discipline in rapid development that borrows and steals from anything that can help shed light on the questions we ask. 


\section{Central theoretical and methodological areas}

I will now present theoretical and methodological areas and concepts of specific relevance for the case studies in focus in this article. These are the tacit dimension of knowledge, reflection-in-action, action research and performance studies.

\section{The tacit dimension of knowledge}

In The Tacit Dimension, Michel Polanyi (2009, p. 4) wrote: "I shall reconsider human knowledge by starting from the fact that we can know more than we can tell." This applies to both practice and performance, and he focuses on the way theoretical and formal knowledge rest on the dimension of experience. He emphasizes that knowledge resides in the body and that the brain knows the world primarily through perception. After using equipment or tools to explore something for a while, we begin to feel not the tool but the thing through the tool. It becomes an extension of the hand; we begin to "inhabit" the tool, a similar experience to dwelling in one's body or clothes. When describing the structure of tacit knowing, Polanyi distinguishes between focal awareness and subsidiary awareness, which are mutually exclusive. "If a pianist shifts the attention from the piece he is playing to the observation of what he is doing with his fingers while playing it he gets confused and may have to stop" (Polanyi, 1998, p. 56). Focal awareness is thus the detailed focus on the fingers, while the subsidiary awareness belongs to the tacit category related to bodily functions (Polanyi, 2009, p. 95-96). The two aspects of "knowing what" and "knowing how" (wissen and können in German) have the same structure. His concept of knowledge can therefore be positioned at the centre of much practice-based research. Polanyi does not present methods to make tacit knowledge explicit, but he prepares the ground and paves the way for others to build upon his theories and concepts and to develop methods for practitioners.

\section{Reflection-in-action}

Donald Schön's concepts learning society, reflection-in-action, and reflection-onaction have been central to practice-based research. Schön's The Reflective Practitioner (1983) brought the concept of reflection into the core of the understanding of what professionals do. His theories are used in several fields, including the field of educational research, teacher education, arts education, architecture, and health sciences. Schön talks about improving work (practice) continuously through improvisation and "thinking on one's feet", and through experience cycles of learning and practice. He writes about reflection in and on action, looking at our experiences, getting in touch with our feelings, and being aware of the theories we use. This leads to new understanding, which is returned to the action in the unfolding situation. ${ }^{3}$

\footnotetext{
${ }^{3}$ See Bengt Molander (2008) for a further discussion of reflection-in-action.
} 


\section{T. Orning}

\section{Action research}

Action research is an umbrella concept for a spectrum of research designs that equates theoretical and practical knowledge, and is widely used in practice-based research (Schwandt, 2001). The goal is to initiate a process that involves reflection, testing and acquisition of new knowledge, with the aim of developing and improving the practice, reforming existing theories and developing new ones. The research design is cyclical, in that it involves a) planning an action, b) carrying out the action, c) following up by observing what happens and d) reflecting on the result, which leads to the planning of new actions (Lewin, 1958, p. 201). Action research considers the process involving questions and reflection as important as the results of the research. Thus, the reflection on practice and the experiments in practice become mutually dependent and equated. The action researcher is experienced and is involved in the field being researched thus the research can therefore not be considered objective or value-free. Parts of the thinking within action research have been inspiring for artistic research, especially the involvement in one's own research and the insight that research is not neutral, as well as the understanding of collaborators (that other people are not being research "objects", but research participants and often co-researchers).

\section{Performance studies}

Performance studies is an interdisciplinary field originating in the U.S. in the 1960s, establishing the action or performance at the centre of investigation (Schechner, 2006). It has become a fast-growing academic discipline during the last fifty years, emerging from theatre studies and now including performing arts and storytelling as well as a wide variety of ceremonies, rituals, and games.

German theatre scholar Erika Fischer-Lichte describes "perceptual multistability" as the constant transition between two orders of perception, presence, and representation: “... [the] oscillating focus between the actor's specific corporeality and the character portrayed" (Fischer-Lichte, 2008, p. 147). The order of presence relates to authenticity and immediacy whereas the order of representation is used when the actor portrays a character by generating a role in the fictive world. Her concept, the "autopoetic feedback loop" describes the reciprocal process between performers and spectators. She challenges the traditional subject/object relationship between actors and spectators, thus: "The bodily co-presence of actors and spectators enables and constitutes performance" (Fischer-Lichte, 2008, p. 132). Although Fischer-Lichte's concepts originate in the field of theatre, I think they can be useful for studying music by exploring the different meanings of and for, and the relationships between the performer, musical text, interpretation, embodiment and instrument.

With this as a methodological and theoretical background, I will now turn to the two case studies (Orning, 2014) from my own practice as a cellist-researcher in focus in this article. 


\section{Projection I, Intersection IV, and Pression - two case studies}

$\mathrm{My} \mathrm{PhD}$ project explored how the cellist's role within contemporary music has changed and been expanded from 1950 till today. The purpose of the project was to investigate and document this new role on the basis of certain central and ground-breaking works from the contemporary cello repertoire.

\section{Projection I and Intersection IV}

Projection I (composed in 1950 and published in 1961, see Fig. 1) and Intersection IV (composed in 1953 and published in 1964, see Fig. 2) by Morton Feldman (192687) are among the first purely graphic scores in the twentieth century. The outline of the notation is a grid where boxes on three levels refer to the high, middle, and low registers. Tempo, timbre, and duration are indicated, but pitch and dynamics are left to the performer to decide. The indeterminate performance parameters raise acute questions about interpretative choices in this music, and in particular, about the degree to which a performer today can experience the freedom of choice invited by the score, given Feldman's dominant voice and the strong performance tradition. The composer actively disassociated himself from the compositional methods and systems prevalent in Europe at the time, dedicating himself instead to intuition in composition and a "non-intellectual" approach to art, an approach greatly inspired by the abstract expressionist painters in his circle.

\section{Projection 1}

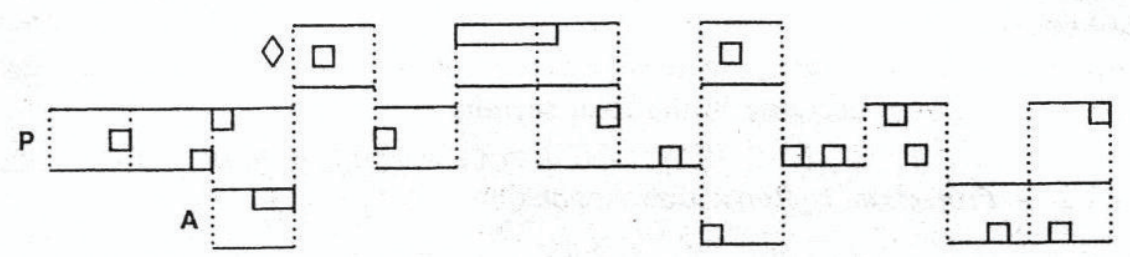

Figure 1. Projection I by Morton Feldman. Copyright (C) 1961 Used by permission of C. F. Peters Corporation. All rights reserved.

I wanted to investigate the paradox that in the performance practice of music by Feldman, a composer who actually allowed freedom to the performer, most performers interpret his music according to what they assume his intentions were, rather than taking the liberties afforded in the score literally. To investigate these questions, I decided to perform an experiment using literary theory to support my examination, including two extreme outlooks on the subject of intentionality. In the first model, I use the term Texttreue, based on the concept of The Intentional Fallacy (Wimsatt \& Beardsley, 1987) where all the information needed for interpretation 


\title{
T. Orning
}

is to be found in the text. ${ }^{4}$ The other model is based on the authorial intent, biography and history of the composer following the idea of the "non-dead" author in contemporary music (Kanno, 2012). In this context, I use the term Werktreue (Goehr, 1992), as the concept of the work can be seen to comprise all these elements. Werktreue (work-fidelity) implies fidelity to the work and, by implication, the composer's intention: it involves a search for the ideal of correct and authentic interpretation of a score. ${ }^{5}$ I critique the issue of intentionality more generally within the performance practice of contemporary music, drawing on Roland Barthes' essay "The Death of the Author" (1977), and Michel Foucault's "What Is an Author?" (2008). After discussing different perspectives on intentionality, I try out these theories in practice, through playing.

\section{INTERSECTION 4.}

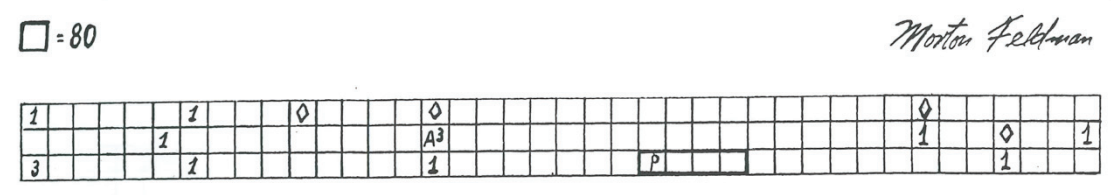

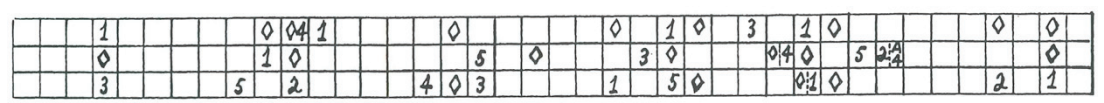

\author{
\% \\ COPYRIGAT (1) 1964 AY C.F. PETERS CORP, 373 PARK AVE. SO, N.Y. 16 N.Y.
}

Figure 2. Intersection IV by Morton Feldman. Copyright (C) (1964) Used by permission of C. F. Peters Corporation. All rights reserved.

I base the Texttreue interpretation of Projection I on textual content only, that is, the information exclusively found in the score, as both graphic signs and written instructions. The mental image of projecting something onto this grid or maze makes me

\footnotetext{
${ }^{4}$ Wimsatt and Beardsley's article "The Intentional Fallacy" first published in 1946, and the American "New Criticism" to which it belonged, promoted objective interpretation of the text, viewed as an autonomous object.

${ }^{5}$ In The Imaginary Museum of Musical Works, (Goehr, 1992, p. 242), Lydia Goehr claims that the Werktreue ideal "pervaded every aspect of practice in and after 1800 with full regulative force." See also Taruskin (1995) and Butt (2002), which summarize the field quite clearly.
} 
choose an abstract sound world, including sounds with properties associated with noise. The squareness of the visual image makes me want to play the piece rather strictly in tempo, although I appreciate the remark "tempo 72 or thereabouts" (Feldman, 1961), which offers me the opportunity to introduce rubato, when the phrasing calls for it or where the physical actions require time for the big leaps in register. The score also brings to mind the scoring of electronic music, with its linearity and lack of noted nuances. With this in mind, I aim for sustained notes bowed evenly and without diminuendo for the entire duration when prescribed in arco, and I try to start the note without a clear attack. As the score contains no dynamics, I try to do this spontaneously during performance, letting the character and timbre of each sound influence the dynamic direction. The author's Texttreue interpretation of Projection I can be seen here. ${ }^{6}$

In order to interpret Intersection IV from a Texttreue perspective, I tried to perform it as literally as possible, which meant playing up to 13 notes within one beat. I used a digital recording technique, allowing me to divide the piece into several voices and record them separately. I wrote out a score with up to 13 voices choosing pitches within each range of approximately a tenth. Naturally this method will not work in a live performance, but as an experiment in realizing Feldman's written ideal, I performed this experiment in order to get as close as possible to the text. The Texttreue, anti-intentionalist, interpretations proved to be a challenging intellectual experiment, as I strove for a tabula rasa in reading the instructions. The obvious fact that no interpretation takes place in a vacuum became increasingly evident over the course of these experiments. My interpretation of the text, however "objective" my goal, will inevitably be conditioned and guided by my previous knowledge and preconceptions. An interesting point is that the "objective" reading of the score became the subjective reading, as I took everything in the score literally including the license to choose after my own heart. This also resonates with what Mieko Kanno calles "the authorship of performance" (2012, p. 178), the performer's creative territory, which in contemporary music is trespassed by the "non-dead" composer. The author's Texttreue interpretation of Intersection IV can be seen here. ${ }^{7}$ The author's Werktreue interpretation of Intersection IV can be seen here. ${ }^{8}$

Applying a Werktreue perspective, I investigated Feldman's plethora of traces, through his scores, recordings, writings, speeches and public appearances, as well as the performance practice of his pieces. Feldman seeks to avoid memory relationships between the pitches, so while practicing, in addition to avoiding the obvious tonal relationships, I also think of Feldman's ideal: "a totally abstract sonic adventure," in which the aim was "to project sounds into time, free from a compositional rhetoric" 


\section{T. Orning}

(Feldman, 1985, p. 38), in choosing pitches. The author's Werktreue interpretation of Projection I can be seen here. ${ }^{9}$

To inform my interpretation, I carried out an investigation of the history, reception and performance practice of Feldman's indeterminate works from the same period. I aimed at an interpretation which is as close as possible to what I supposed Feldman's intention would be. It became clear to me that this was a familiar position, from which I instinctively acted upon the belief that to be true to the work is largely to be true to its creator - the two all but inseparable. This position, embedded in my musical upbringing and reflected in my practice came to the surface and became more discernible through this experiment, which led to reflection on the powerful influence of context and the notion that no interpretation takes place outside context.

I recorded the sounding result of the experiment on a DVD which was enclosed in my dissertation. The two different interpretations of Projection I and Intersection $I V$ vary significantly, in sound, pitch content, phrasing, rubato and overall character. However, I think the listener still may perceive the identity of the work across these deviating performances. Despite Feldman's "freeing" of the pitches, the remaining determinate parameters surprisingly seem to hold the work together, to an identifiable and recognizable entity.

\section{Pression}

Helmut Lachenmann (b. 1935), the leading composer of the German post-war generation, is constantly seeking ways in which music can serve as a road forward after the Holocaust, seeing music as a fundamentally existential activity. In Pression (1969), conventional notation and all of the classical sound ideals are abandoned, and the work creates a new sound aesthetic in instrumental music. The author's performance of Pression can be seen here..$^{10}$

The notation is created from point zero: it does not describe the sounds, but rather the cellist's actions or methods in creating sounds, a method derived from tablature called prescriptive notation (Kanno, 2007; Seeger, 1958), action notation or action-based notation (Kojs, 2011), to distinguish it from descriptive notation (otherwise known as traditional notation). The composer calls this radical approach to instrumental sound production "musique concrète instrumentale" (Lachenmann, 1996, p. 381). ${ }^{11}$

Drawings or maps of the cello and bow, as well as arrows and lines, indicate where the cellist is asked to stroke, rub, and knock on the instrument. Lachenmann asks the performer to play by heart or with a very low music stand so that the audience can

\footnotetext{
${ }^{9}$ https://vimeo.com/242038440 (accessed 09.11.2017)

${ }^{10} \mathrm{https} / / /$ vimeo.com/242038057 (accessed 09.11.2017)

${ }^{11}$ The composer introduced the term (in German, instrumentalen Musique concrète) in his brief account of Pression (1996) first published in 1972.
} 

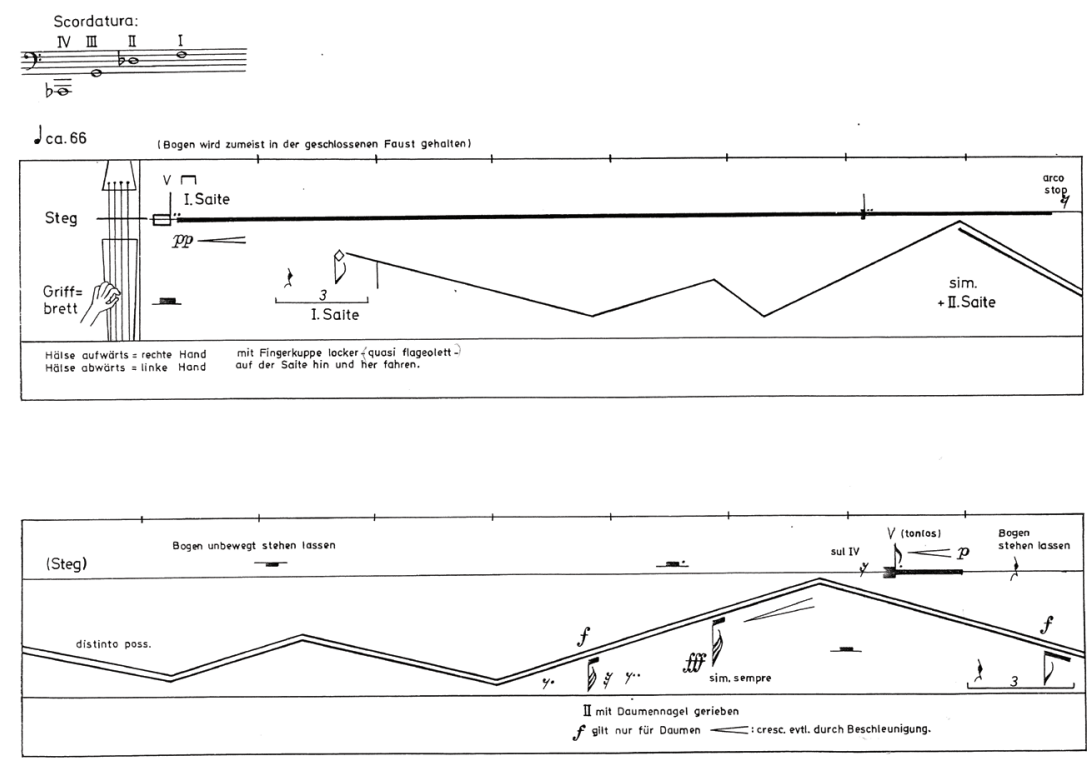

Figure 3. Helmut Lachenmann Pression (C 1972 by Musikverlage Hans Gerig, Köln. 1980 assigned to Breitkopf \& Härtel, Wiesbaden. All rights reserved.

see both cellist and cello, as the performance contains unusual physical and gestural aspects, and the relation between action and sound is foregrounded. The central question is how to understand Pression: not as a work (self-) contained in a score, but as a live object, as sound, performance, action and embodiment. My analysis here draws primarily upon perspectives from the field of performance studies, and performance theory by Fischer-Lichte (2008).

When I perform the "character" Pression, I "stage" the piece through the score and my ideas of the composer's intentions on the one hand, and my body's interaction with my instrument on the other. My awareness in the course of the performance moves constantly between these factors. Fischer-Lichte's term perceptual multistability refers to these unpredictable modes of perception or:

[...] change of direction" during the very act of perceiving. The perceiving subjects find themselves on the threshold which constitutes the transition from one order to another [presence, and representation]; they experience a liminal state. (Fischer-Lichte, 2008, p. 148).

Richard Schechner illustrates a related quality "as transitional, suspended between 'my' behaviour and that which I am citing or imitating" (Schechner, here in Loxley, 2007, p. 157) with the example of Laurence Olivier speaking the famous words "To be or not to be" in Hamlet:

The words belong, or don't belong, equally to Shakespeare, Hamlet, Olivier [...] So Olivier is not Hamlet, but he is also not not Hamlet. The reverse is also true: in this production of the play, Hamlet is not Olivier, but he is also not not Olivier. 
Within this field or frame of double negativity choice and virtuality remain activated (Loxley, 2007, p. 158).

The "staging" aspect in performance of musical works is further discussed by Nicholas Cook: "Thinking of the music as 'script' rather than 'text' implies a reorientation of the relationship between notation and performance" (Cook, 2003, p. 206).

I use Fischer-Lichte's concept of "the autopoietic feedback loop" to investigate experiences I had in performances of Pression, when the audience influenced my performance. In a concert at 7 a.m. where the audience was drowsily listening, the endpin of my cello started to slip on the floor. I had to use all my concentration and force to stop the cello from slipping. While struggling physically and mentally with this, the audience gradually perceived the "drama" in front of them, straitened up, and became extremely attentive. One member of the audience said afterwards:

In this moment, the performance changed from being a good performance to becoming a fantastic performance, when it appeared to be a fight for the music, so to speak. I remember thinking: "will she make it?" To me it seemed that she not only fought to hold on to the instrument, but also to hold on to the intensity of the music (Gravgaard Madsen, 2010).

The energy in the room changed, and I experienced a direct contribution and support from the audience in my struggle to complete the performance. In this way, the performance could be seen close to Herrmann's definition, "played by all for all" (Herrmann, 1981, p. 19). There is no longer a gap between the audience and the stage; the two parties influence each other.

The prescriptive notation used in Pression presents actions and gestures as musical material, although their primary purpose is not to produce sound. The score is transformed into a process, a performative process, where the written text is only one element in the whole event. The increasing precision of performance parameters and the emergence of extended techniques in instrumental practice has also forced the notational practice towards the "doing" aspect of notation. What happens, then, when the work-concept is challenged, when the work is no longer to be found complete and innate in the score, but is dependent upon performance to be fully constituted? This is a new direction in performance practice, in which constitutive elements of the work are moved into the performative domain through the instrumental practice, making each performer's physical and mental predispositions decisive factors in the interpretation. The actual playing of the instrument, the instrumental practice, has become the compositional material. The musician's actions, specific performance parameters and bodily movements are notated. Instrumental practice is in this way woven into the score through its notation, so that the score cannot be seen as separate from the instrumental practice. In other words, the score cannot be fully understood without being performed. This can be seen as an extreme idiomatic approach, beyond instrumental idiomatic virtuosity, extended to encompass the specific instrument and musician's actions in the moment of performance. 


\section{Discussion}

In this concluding section I discuss my research question, How can I relate and network the pluralism of methods in music research involving artistic practice? in relation to my two case studies and more generally within artistic research.

My study is investigating music and practice, performance and scores, abstract intentions and physical expressions. Performance studies and artistic research have represented my overarching perspective, acknowledging the performance perspective and experience to be at the heart of this research. This can be described as my methodology: my overarching frame of interpretation, or my research design. This methodology is a bricolage of primary research from practice combined with textual and music analysis, in line with Borgdorff's methodological pluralism or the related term methodological abundance (Hannula, Suoranta \& Vadén, 2014, p. 20). The concepts I presented in central theoretical and methodological areas in this article have aided me in reflecting and relating the variance of methods in my research. Active reflection around my different and changing roles as performer and researcher, using perspectives from action research, has helped me become aware of elements I have taken for granted. Schön's reflection-in-action, and reflection-on-action as well as Polanyi's tacit knowledge, have expanded the discourse on practice-led research, offering a theoretical foundation for the embodied knowledge implicit in artistic practice.

In the Feldman example, I used theory and history to construct a framework within which I conducted musical performance experiments. My initial work covered musicological investigations such as historical studies of performance practice including recordings, analyses, accounts from performers and the composers own writings. My choice to include literature theory was in order to apply new perspectives on the performers strong, faithful and often unquestioned relationship to what are assumed to be the composer's intentions (Werktreue). The framework served as an analytical tool in discussing experimental interpretations made under certain conditions. Through these experiments, my performances, both in technical choices and musical interpretations, served as arguments in the discussion. In this way, the discussion took place on two levels: firstly, the artistic, musical one, performed through the instrument, producing an artistic result which "discusses" the framework on a sounding level, the music speaking for itself. Secondly, the written discussion, in the form of an argument following the experiments and taking the sounding "arguments" into account. In this way, I related the artistic methods to the theoretical framework I constructed, and networked these layers both in the written and the sounding output.

Pression by Lachenmann is one of the most iconic, frequently performed, and researched contemporary works within musicology. By applying a performance studies lens, by looking at Pression as something (a)live, I methodologically went ahead to investigate what the work is actually doing (performing). In investigating what kind of impact Pression has had on the history as well as on the performer and 


\section{T. Orning}

audience, in using several methods and theories, I let the historical and theoretical knowledge inform my interpretations of the work and vice versa, in a cyclical movement over the course of three years. Working with the composer in the performative domain, I gained new insights about concrete performance details both technical and interpretative, knowledge not communicated in the score (Orning, 2012, p. 21).

The musical works I have chosen, implicitly critique conventional performance practice by challenging and confronting essential aspects of practice, causing the performer to question habits and ingrained patterns. Within this practice, with a greater emphasis on the body and a move from Werktreue to more non-linear and ambiguous approaches, I see the role of a more critical and self-reflective performer emerge.

The core of both the musical practice itself and writing about musical practice revolves around interpretation. This interpretation involves an interplay between artistic practice and reflection on the practice. The activities of interpretation can also be regarded as a kind of analysis. Describing a hermeneutic analysis, Arnold Whittall claims that "Analysis is interpretation - even a kind of performance, in the sense that analysts explore the materials and meanings of compositions and attempt to communicate their findings, through speaking or writing" (Whittall, 2013). When parts of the exploratory analysis take place through the instrument, this approach is solidly placed within the musicological field, acknowledging the performative aspects of the research. The statement also emphasizes the performative function of writing, which leads to the questions about what the text does, what it performs. Language is fundamental to how we experience and make sense in the world. Theodor Adorno speaks of the relation between music and words:

Music resembles a language. Expressions such as musical idiom, musical intonation, are not simply metaphors. But music is not identical with language. The resemblance points to something essential, but vague. Anyone who takes it literally will be seriously misled. (Adorno, 1992, p. 1)

Adorno here points to what can be seen as the crux of music performance research, the difficult task of translating musical experiences into reflection and writing. In the process of writing my way through reflections, considerations and experiences related to the material, and of discussing the performance choices made under certain conditions, I have produced a different kind of knowledge than that of the purely performative. I have made explicit a knowledge and way of knowing that usually remain implicit within the practice. Only by investigating the works from inside the practice will they divulge a knowledge that cannot be accessed from outside the work itself. In this way, the performer's perspectives offer not only a unique position in the research but also, as we have seen, a method or tool for generating and producing knowledge. My methodological approach is not new, but my methods in relating and networking the chosen theory and practice may be seen as a contribution to the further development of methods and methodology in the field of artistic research and performance studies. 
A pertinent question is what kind of knowledge is not produced in my research. For example, I have not conducted structural analysis of the works which could have given more details about the works as scores. Although I draw on several performers' outputs, I have not made comparative analysis of different performers playing the same work, which could have given knowledge of pluralism in interpretation, or how large the performers see the interpretational space as being in this specific performance practice.

In research on practice, ethical perspectives are constantly present. In my opinion, being ethical means being true to your own project and values, committing yourself to your own research and chosen artistic material and daring to explore something to its fullest potential in your own artistic practice and in society. This can be seen as conflicting with elements in our contemporary and fragmented culture which promotes freedom of choice, flexibility and adaptability. Ethical aspects often involve ambiguity and ambivalence. As artists, this can feel problematic because we are raised to be goal oriented. Daring to exhibit the failures and unsuccessful attempts is a critical part of making the research process transparent and transferable. Performance studies and artistic research are a young field in the making. Even if a musical practice is an aesthetic practice, and several dimensions are evasive and escape analysis, it is important that performer-researchers keep bringing artistic knowledge and perspectives into the research discourse and thereby further develop artistic knowledge and challenge and contribute to new research practices.

\section{Author Bio}

Tanja Orning $(\mathrm{PhD})$ is a cellist and music researcher active in the fields of contemporary and experimental music. After studies in Oslo, in London with William Pleeth and at Indiana University with János Starker (as a Fulbright Research Fellow), she held the position as a co-principal cellist in the Stavanger Symphony Orchestra for 5 years. She left for Oslo again in order to realise a number of projects as a performer, improviser and composer: Cellotronics (solo), ensemble asamisimasa, Kyberia, Ametri quartet, Christian Wallumrød Ensemble, Boa trio, Dr. Ox duo, the performance group Mobile Homes and Wunderkammer. Orning has commissioned and premiered approximately 100 new works by composers in Norway and abroad, including Simon Steen-Andersen, Natasha Barrett, Maja Ratkje, Øyvind Torvund, Johannes Kreidler and Mathias Spahlinger. She has performed at festivals such as Darmstadt, Donaueschingen, Huddersfield, Ultima, Ultraschall, Novembermusik, Wien Modern, Taktlos (Zürich), Other Minds (San Fransisco) and Portland Jazzfestival. Besides being an active performer, Orning works as a post-doctoral researcher and teacher at the Norwegian Academy of Music.

\section{References}

Adorno, T. W. (1992).Quasi una Fantasia: Essays on Modern Music. (Translation by Rodney Livingstone). London and New York: Verso.

Barthes, R. (1977). The Death of the Author. In S.Heath (Ed.), Image, Music, Text. Essays selected and translated by Stephen Heath (pp. 142-148). London: Fontana Press.

Borgdorff, H. (2010). The Production of Knowledge in Artistic Research. In M. Biggs \& H. Karlsson (Eds), The Routledge Companion to Research in the Arts (pp. 44-63). London: Taylor \& Francis.

Butler, J. (2006). Gender Trouble: Feminism and the Subversion of Identity. NewYork and London: Routledge Classics.

Butt, J. (2002). Playing with History: The Historical Approach to Musical Performance. Cambridge: Cambridge University Press.

Cook, N. (1999). Analysing Performance and Performing Analysis. In N. Cook and M. Everist (Eds), Rethinking Music (pp. 239-61). Oxford: Oxford University Press. 


\section{T. Orning}

. (2003). Music as Performance. In M. Clayton, T. Herbert \& R. Middleton (Eds.), The Cultural Study of Music: A Critical Introduction (pp. 204-214). London: Routledge.

- (2013). Beyond the Score: Music as Performance. New York: Oxford University Press.

- (2015). Performing research. In M. Doğantan-Dack (Ed.), Artistic Practice as Research in Music: Theory, Criticism, Practice (pp. 11-32). Aldershot: Ashgate.

de Assis, P. (2015). Epistemic Complexity and Experimental Systems in Music Performance. In D. Crispin \& B. Gilmore (Eds), Artistic Experimentation in Music, An Anthology (pp. 41-54). Leuven: Leuven University Press.

Doğantan-Dack, M. (2012). The Art of Research in Live Music Performance. Music Performance Research, vol. 5 34-48. http://mpr-online.net/Issues/Volume\%205\%20[2012]/Dogantan-Dack.pdf (accessed 29.10.2017).

Feldman, M. (1985). Morton Feldman Essays, ed. W. Zimmerman. Kerpen: Beginner Press.

- (1961). Projection 1. New York: Peters. . (1964). Intersection IV. New York: Peters.

Fischer-Lichte, E. (2008). The Transformative Power of Performance (trans. Saskya Iris Jain). Oxford: Oxford University Press.

Foucault, M. (2008). What Is an Author? In D. Lodge \& N. Wood (Eds), Modern Criticism and Theory: A Reader (pp. 281-93). Harlow: Pearson Education.

Goehr, L. (1998). Conflicting Ideals of Performance in an Imperfect Practice. Oxford: Oxford University Press. . (1992). The Imaginary Museum of Musical Works. Oxford: Clarendon Press.

Hannula, M., Suoranta, J. \& Vadén, T. (2014). Artistic research methodology: narrative, power and the public. New York: Peter Lang.

Haseman, B. (2006). A Manifesto for Performative Research. Media International Australia incorporating Culture and Policy, theme issue Practice-led Research, no. 118, 98-106. http://eprints.qut.edu.au/3999/1/3999_1.pdf (accessed 20.09.2017)

Herrmann, M. (1981). Uber die Aufgaben eines theaterwissenschaftlichen Institutes. In H. Klier (Ed.), Theaterwissenschaft im deutchsprachigen Raum (pp. 15-21). Darmstadt:Wissenschaftlige Buchgesellschaft.

Kanno, M. (2007). Prescriptive notation: Limits and challenges. Contemporary Music Review, 26(2), $231-234$.

- (2012). As If the Composer Is Dead. Mortality: Promoting the Interdisciplinary Study of Death and Dying, $17,170-81$.

Knorr Cetina, K., Schatzki, T. R. and von Savigny, E. (Eds) (2001). The Practice Turn in Contemporary Theory. London: Routledge.

Kojs, J. (2011). Notating Action-Based Music. Leonardo Music fournal 21, 65-72.

Lachenmann, H. (1972). Pression. Wiesbaden: Breitkopf \& Härtel.

—. (1996). Musik als existentielle Erfahrung: Schriften 1966 - 1995. ed. Josef Häusler. Mainz: Breitkopf und Härtel.

Lewin, K. (1958). Group Decision and Social Change. New York: Holt, Rinehart and Winston.

Loxley, J. (2007). Performativity. London: Routledge.

Madsen, A. G. (2010). Private email correspondence.

Molander, B. (2008). Have I kept inquiry moving? On the Epistemology of Reflection. Phenomenology E Practice, vol. $2,1,4-23$.

Nelson, R. (2013). Practice as research in the arts: principles, protocols, pedagogies, resistances. Basingstoke: Palgrave Macmillan.

Orning, T. (2014). The Polyphonic Performer. (Diss.) Oslo: Norwegian Academy of Music.

- (2012). Pression - A Performance Study. Music Performance Research, vol. 5, 12-31. http://mpr-online. net/Issues/Volume\%205\%20\%5B2012\%5D/Orning.pdf (accessed 29.10.2017)

Polanyi, M. (2009). The Tacit Dimension. Chicago: University of Chicago Press.

- (1998). Personal Knowledge: Towards a Post-Critical Philosophy. London: Routledge.

Raes, G.W. (2014). Experimental Art as Research. In D. Crispin \& B. Gilmore (Eds.), Artistic Experimentation in Music, An Anthology (pp. 55-60). Leuven: Leuven University Press.

Schechner, R. (2006). Performance Studies: An Introduction. London: Routledge.

Schwandt, T. A. (2001). Dictionary of Qualitative Inquiry. Los Angeles: Sage.

Schön, D. A. (1983). The Reflective Practitioner. How Professionals Think in Action. New York: Basic Books.

Seeger, C. (1958). Prescriptive and descriptive music-writing. The Music Quarterly, 44 (2), 184-195.

Taruskin, R. (1995). Text and Act: Essays on Music and Performance. Oxford, New York: Oxford University Press.

Whittall, A. (2013). Analysis. In A. Latham (Ed.), The Oxford Companion to Music. Oxford: Oxford University Press. http://www.oxfordmusiconline.com (accessed 29.09.2017).

Wimsatt, W.K. \& Beardsley, M. C. (1987). The Intentional Fallacy. In J. Margolis (Ed.), Philosophy Looks at the Arts: Contemporary Readings in Aesthetics, (pp. 367-80). Philadelphia:Temple University Press. 